\title{
S
}

507

. N54L2

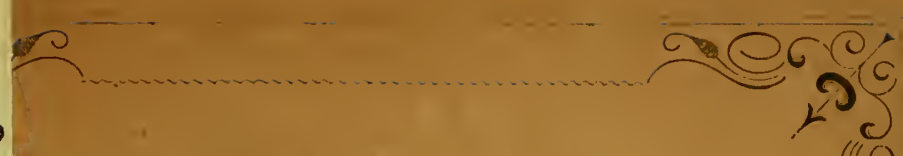

\&)

\section{PRACTICAL IINTS}

Ir

\section{GLANCE UPON FARMING}

WRITIEX FOR THE

WEYMOUTH STOCKHOLDERS.

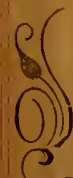

PHILA DELPHIA.

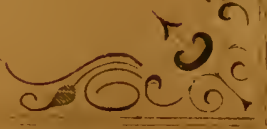




$$
\%
$$




\section{PRACTICAL IIINTS}

AT A

\section{GLANCE UPON FARMING}

WRITTEN FOR THE

WEYMOUTH STOCKHOLDERS.
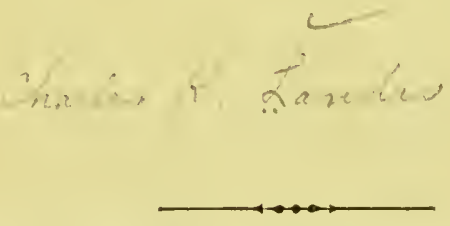

PHILADELPHIA.

1855. 


$$
\begin{aligned}
& 507 \\
& \text { id } 54 L 2
\end{aligned}
$$




\section{PRACTICAL HINTS ON FARIING.}

To the Stockholders of the

Weymouth Farm and Agricultural Co.

Gentlemen:

As many of you wish to improve your farms, and perhaps have not had the leisure to acquire the particular information as to the most economical and feasible methods, the undersigned has taken the liberty of presenting you with a few hints, which, he can only flatter himself, may give rise to better and more important ones in your own minds. Such as they are, howerer, he believes they will be found substantially correct, as he has not relied so much upon his own judgment, as that of persons who have lived upon the property, and from actual experience become familiar with the requirements necessary to cultivate the land with profit and success.

The matters which will first come under consideration, will be-

1. The course Stockholders should pursue when going upon the land.

2. First thing necessary to be done.

3. Implements at first required.

4. Qualities of the soil.

5. Products the most suitable to each particular quality. 
The course Stockholders should pursue before going upon the land.

In embarking in any undertaking, the great and supreme object we have in view, is to make it successful, and profitable. To do this, it is necessary to provide against every difficulty, and place it beyond the power of circumstance or chance to defeat our purposes. These remarks are so applicable to the present undertaking, that they can be fully carried out. In order to do so, I would suggest an unity of action amongst different classes of Stockholders; that is, instead of going upon the land separately and alone, they form small sub-companies of from ten to twenty. This can be done amongst particular friends or persons, whose reliability will give confidence. By thus harmonising together, a large amount of stock can be saved. The knowledge that one does not possess, another will. There will always be some who are well informed upon the practical operations of a farm, and who can thus give a guiding hand to the less experienced. This consideration is of the highest importance, as upon it deperids the profit-the saving of labor and money, and is enough alone to demonstrate not only the benefits to be derived from the association of friends, but its absolute necessity. Each member will be possessed of some qualifications to make him of advantage to the whole. The expense of a great deal of separate carrying can be saved; instead of its being necessary for each person when they are in want of any implement, or the like, to go to the expense of a journey to the city, thus neglecting their affairs, and 
losing time, they can, by joining together, authorise some honest and reliable agent to attend to their business. The best method for carrying this principle out, is for friends or persons intending so to associate together, to have their farms adjoining, and make their selections from the land with an eye to the products they wish to raise. After they have entered upon it, being near neighbors, they should have meetings each week for the purpose of gaining information of each other; or, at least, make such organization as they find to be most judicious. If this plan is carried out, I am satisfied that the hopes and anticipations of every man will be realized, and more. There is no wider field in the Union presented for obtaining a home and an independence, than in the security of a profitable farm, lying directly between two markets, where the soil is the most suitable of any for raising the products most in demand. To fail is out of the question, provided the principles of success are in the least observed. Mutual incitement is a powerful progressor; under its influence the idler will work, when he otherwise rould be weak and discouraged. The uninformed will soon learn, and, in short, your objects will be accomplished.

\section{II.}

First thing necessary to be done.

1. The first care is to build a house that will answer the temporary purposes of the farmer. But as all labor, as well as money, should be economised, it is advisable to bestow sufficient care and taste upon it to make it suitable to form a part of a more extended building. The locality should be convenient to the fields and out-buildings, yet easily accessible to the 
highway, about a sufficient distance to make a fine row of trees leading from the gate to the dwelling; this adds both value and ornament to a property, and is one of the most beautiful features that can be introduced. It should be generally observed. A stone house is cooler in summer and warmer in winter, whilst it is more permanent and economical; frame attracts vermin and requires frequent re-painting, or it is soon possessed of a poverty-stricken appearance. The outlay for a stone house is about the same, and it always looks better. In building, an eye should always be had to ultimate value; ornamental styles, whilst they are richer and more tasteful, cost no more than the plain and old fashioned. In the sale of a farm, a house of this kind, being an ornament to the property, will make a difference, very often, of 50 per cent. Where there are private companies, a convenient and substantial dwelling might at first be erected, to accommodate the owners of several adjoining farms. This is a matter which should be well considered, as by it time and expense will be saved, and stockholders be brought oftener together. A small but comfortable house can be built for from three to five hundred dollars. Reliable builders are already located at Colville, from whom plans and specifications can be obtained. In regard to barns and out-houses, this is a matter of which Stockholders will have more time to consider, and they can be erected as necessity requires. But there is one thing which, above all others, I would suggest, and that is that all out-buildings and in fact any buildings requiring it, should be white-washed once a year. It will make them last twice as long, add to their value, be a saving of money, present a beautiful appearance, and be a credit to the owner. Where it is not done, it is a positive disgrace. It looks poverty-stricken and neglectful, and is not only a disgrace to the country, but the farmer, as it is apparent that he has not the intelligence to 
know his own interests. We always find those who understand their business, very careful about the neatness and economy of their properties, and above all things this should be the characteristic of Weymouth Stockholders.

\section{2.-Fencing.}

In this country there is more fencing than is necessary.That which is done should be done well. A large area of fences is generally neglected, and through it cattle contract the habit of disregarding them and clestroying the crops. Where the fences are of the strongest and best kind, the animals are usually found tractable and of good habits. The consideration, therefore, should be to have as little fencing as possible, but that of the best kind. If every field or patch is separately fenced off, whilst it serves no better to keep the cattle outa great outlay of money is incurred-whilst attention to repairing and kecping it in order requires a great deal of time and expense. The land which it is intended to work, should be the first enclosed. The old-fashioned worm fence is the cheapest, on account of the facility with which Pine and Cedar rails can be obtained-much of the slender timber already answering that purpose. I will give a separate account of the different kinds and expense, so that in their choice, Stockholders can use their discretion.

A pine fence of this kind, which will last five years, and if white-rashed, longer, will cost eight cents a panel-of cedar 25 cents-post and rail fence will cost 75 cents a paneI-a worm panel is 9 feet long-post and rail 10 feet. All rails are generally cut 11 feet long. Wire fencing 20 feet long, will cost $\$ 1$ a panel, including painting. Cedar fence or Wire will list at least 50 years and perhaps longer. Hedges pre- 
sent a very beautiful appearance, but where timber is plentiful, it is doubtful whether it is as cheap-they harbor a great deal of vermin, and require much attention. As a matter of fancy they look very beautiful around gardens and pleasure grounds. The orange hedge is mostly used in the South and West.

\section{3.-Grulbing.}

This is an important part of the first duty of the farmer, and he who does it best invariably succeeds most. By proper attention, a farm can be made to work as easily as though it had been ploughed for 20 years, and this desirable end accomplished without costing a cent. The best plan is to grub before the timber is taken off. This is done with a grubbing hoe and axe. The roots are cut first, and the tree serves as a lever for tearing it up. This process is simple and thorough, whilst the advantages are immense. The principles of economising to clear the expenses, are these : The large grubs should be burnt to charcoal, for which purpose it is superior to most anything else, and commands a very high price. The small should be used for fuel, and the ashes carefully saved for manure, of which it makes the best kind. Mr. Thackeray, who resides upon the tract, and is a most practical farmer, has tested this by experience. Independent of the thorough clearing the land thus receives, the benefit for agricultural purposes is much greater. The soil is mellowed equally, and an excellent coating of manure is obtained, formed by the decomposition of vegetable matter. Moreover, when the land is once grubbed thoroughly, the work is done-there is no breaking of ploughs, or injuring of horses. The sprouts and nettles that spring up where it is half attended to, cost as much eventually, as the original expense, whilst they consume the manure and take the 
strength of the soil as much as the crops. The operation should be thoroughly performed for $\mathbf{1 4}$ inches in depth, in order to take advantage of sub-soil.

III.

Implements at first required for a farm of from 20 to 40 acres.

R. L. Allen, in his excellent work upon Agriculture, observes "There has been a 'penny wise and pound foolish' policy adopted by many farmers, in their neglect or refusal to supply themselves with good tools to work with. They thus save a fer shillings in the first outlay, but frequently lose ten times as much by the use of indifferent ones, from the waste of labor and the inefficiency of their operations. ${ }^{7}$ A farmer should estimate the value of his own and his laborer's time, as well as that of his teams, by dollars and cents; and if it requires thirty, ten or even one per cent. more to accomplish a given object with one instrument than with another, he should, before buying one of inferior quality, carefully compute the amount his false economy will cost him before he is done with it. Poor men or those who wish to thrive, can ill afford the extravagance of buying inferior tools, at however low a price. The best are always the cheapest; not those of high extravagant finish, or in any respect unnecessarily costly, but such as are plain and substantial, made on the best principles and of the most durable materials."

The following enumerated implements are those which it will be necessary to eommence with; others can be obtained as required. The particular kind or make of instruments mentioned, 
is such as has been found absolutely necessary for this land, and in the selection, therefore, particular attention should be paid to it.

2 Grubbing hoes and axes. The best that can be had are made at Williams' Tool and Implement Manufactory, on the east side of the Germantown Road, second door above Phonix Street, Philadelphia.

1 Wrought Iron Peacock Plough, No. 5.

1 Harrow.

2 or more Shovels.

1 Spade.

3 or more Hoes.

3 Forks for Manure.

1 Gravel Rake.

1 Hay Rake.

1 Wheelbarrow.

1 Cart.

1 Grindstone.

1 Straw Cutter.

1 Horse, Harness, Curry-comb, and Brushes.

A small Chest of Carpenter's Tools.

IV.

Qualities of Soil.

There is every quality of soil upon the Weymouth Tract, that can be desired for agricultural purposes. It possesses not only the particular kind necessary, but that of the best. There is no land in the State, which for variety of soil, richness and fertility, can claim superiority over this. Before it 
was lnown, it was considered a matter which could only be ascertained by a more thorough knowledge of its nature than any then possessed, or by experience in practical farming. Since then both have been obtained. The opinion of well informed agriculturists, who have traversed the property, has been such as to elicit their public enconiums, whilst a good scientific farmer, of enlarged and extended views, has raised upon the property itself, the finest crops, and converted his own farm into a garden spot. The Hon. William Parry, of Cinnaminson, Burlington county, New Jersey, (one of our most eminent agriculturists and the proprietor of the horticultural gardens,) in 1854 , before any of this land was thrown in the market, spent several weeks upon it, superintending a survey made for Stephen Colwell, Esq., the previous owner. He went there, as he remarks, with all the prejudices incident to those who know nothing of that part of the State; but after he became thoroughly acquainted with its qualities, he was so agreeably disappointed, that he considered the impressions abroad in respect to it, a public misfortune. He accordingly addressed a letter for publication to the "Camden Democrat." It appeared in that paper on the 16th of September, 1854.

I will give his own words in respect to it.

"Having spent several weeks in this country, surveying what, in common parlance, is called "Jersey Pines," the prejudices which, in common with others, I had previously entertained against them, has been displaced by a more intimate acquaintance with their true merits. The wood which covers most of the the high table land, and has heretofore been considered an incumbrance in the way of cultivating the soil, now readily commands from three to four dollars on the ground. * *

The borders of the streams abound with cedar of the finest quality; the hills with excellent building stone, and the valleys 
with springs of soft water. The nature of the soil is generally sandy or a mellow loam for a few inches on the surface, which is underlaid by a sub-soil strata of gravelly loam and clay, so very essential to retain moisture and nourishment for the support of fruit trees, plants and cereal crops, and accounts for the unusually healthy appearance and luxuriant growth of the peach trees now before my view, laden with luscious fruit, bending their branches in graceful curres, nearly or quite to the ground, and which the owner informed me were planted more than fifteen years since; still they show no signs of decay. Apples, peaches and other choice fruits, also potatoes, vegetables and perishable articles, have heretofore been cultivated only for family use-the distance to Pennsylvania was so great to haul them by land in good condition, but now they can be sent there by the railroad within two hours from the time they are gathered, retaining all the flavor and richness of fruit that has ripened where it grew.

Land, naturally good and well adapted for raising apples, peaches, pears, strawberries, raspberries, and all the choice fruits that sell so high in the city, can yet be purchased here at prices not exceeding what is paid annually in rent for land no better adapted for that purpose, located near the city, where the time and cost of hauling the crops to market in wagons, is as great as is required to send them from here in the cars.

Peach trees generally do so much better on new land than on any other, and will not succeed at all on ground where they have previously been grown - that I know of no better opening for enterprising men than to establish large orchards, which I think would soon equal and surpass the celebrated Delaware orchards-for it is in vain to plant the same stock of trees on any ground during the same generation, and Delaware must soon yield up the supremacy to some other untried section." 
In fact, the soil is well adapted to the cultivation of any of the products of this climate. It may be thought a somewhat bold assertion, but it will be verified by the actual truthand that is, there is no better land to be procured for agricultural purposes than this, in any district or locality whatever. There is plenty of manure upon the tract. It is well watered, and in situation the land lies warm. Vegetation can here be ripened and ready for the market, two weeks earlier than in the districts now cultivated to supply the summer luxuries.

The different qualities of the soil are as follows:

1. A small amount of stony soil, mixed with clay and loam. The stone, which ean be saved in clearing, will be found profitable, as it meets with a ready market.

2. Fine gravelly soil, mixed with clay and loam.

3. Sandy soil, with a clay loam bottom.

4. Loam-consisting of sandy loam and clay loam.

5. Clay soil, covered with loam. Some of the clay is of the best quality, suitable for either Potters or Brickmakers.

6. A small amount of swamp, which can easily be drained, when it is the best meadow land-capable of being turned into the best grazing farms in the State. It is also valuable to have a small portion to manure the farm, from its rich regetable deposit of muck. The water upon this land is not standing, but running, so that fever and ague is not known in this part of the country.

After having selected and cleared the kind desired, the manner of ploughing is a most important consideration. On this tract the sub-soil is the best, and at all events, land should be ploughed deeply - skimming over it is most costly indolence, 
whilst going down 10 or 15 inches will pay five-fold for the labor required. The best farmers, both in New Jersey and Pennsylvania, are the most particular in this respect.

V.

Different productions most adapted to each particular kind of soil.

1. Stony soil is always, when found upon this land, mixed with clay or sandy loams. The stones are not so numerous as to make them much of an inconvenience; they are easily removed, and then they are suitable for building. They meet, as observed before, with a ready sale, and yield a profit. The soil, after the stones are removed, is suitable for wheat, rye, oats, grasses, elovers, Indian corn, and all other grains generally; also potatoes, beets, turnips, cabbage, and most of the regetables.

2. Gravelly soil-mostly mixed with clay and loam; the land is not quite so good as some others; it requires a little better working; the same kind of crops will suit this as the previous.

3. Sandy soil. This, through ignorance, is generally not appreciated as it should be. Though it will not grow the heavier products, such as wheat, corn, and the like, yet it will yield erops which are far more profitable than even these. Sweet potatoes, peas, and all kinds of early vegetables, will spring up luxuriantly within a short time. Fruits, such as peaches, apricots, and the like, grow better in this land than any other. No more profitable business could be started than planting extensive peach orchards after the same style as those of Delaware. The Cranberry is an article which is now beginning to receive 
the attention it deserves; it has long been the opinion that they flourish better in low marshy land than upland. This is proven to be a mistake; those raised upon the high and sandy soils are much larger and sweeter than the other; the sandier the soil the better; it cannot be too much so, and as this land generally sells cheap, whilst if the cranberry is properly cultivated, it is raised easily and profitably, there is nothing which will pay better. In fact the profits are enormous, and it is only now that is properly appreciated. For those who wish to go into an easy trucking business, this is the soil to select. On account of the nature of it, it produces full two weeks earlier in the spring than land in the same latitude upon the Delaware River. This is an advantage which is weighty in dollars. Those who are first in the market with the early products, invariably make the most money. Under the upper soil there is generally a rich loam. It works very easily, and if ploughed deeply, in real Pennsylvania style, it may be made suitable for almost any purpose.

4. Loam soil. This is suitable for growing anything whatever, it is the richest and most valuable kind.

5. Clay soil upon this tract is generally mixed with loamit is better than the stony soil-it is suitable for raising all kinds of grain, grasses, clover's, and the like. Where the top soil is of a sandy nature, it is excellent for growing grapes. The grape culture in this country, is beginning to receive considerable attention. There is no place in the United States, where the soil is more suitable for it, or where it can be carried on more profitably than here. When manufactured into light wines it pays splendidly, and the situation being directly between two of the best markets, New York and Philadelphia, it is the very place to commence its culture. 
6. Swamp land. The small amount upon the tract, renders it very valuable. It contains rich deposits of vegetable matter, which makes the richest kind of manure for the upland. At very little expense it can be drained, when it makes the best growing and most luxuriant meadow, and is suitable for anything that requires a rich soil, such as grazing land, or the like.

These few, but practical hints, may be sufficiently suggestive upon this subject. In fact, to go into details, would be too elaborate, and fall short of its objects. As to the different seasons for sowing crops, and the particular minutix which should be observed in respect to each, this information can all be obtained from the best works upon agricultural subjects. I would recommend the American Farm Book, by R. L. Allen, and the American Fruit Agriculturist, by J. J. Thomas. They can be obtained in any of the principal book stores. The Pennsylvania Farm Journal, would also be a great assistant. It contains information adapted to each month. No man, no matter how thorough his acquaintance with agriculture, should be without these books. They contain complete and correct instructions in reference to manuring, which alone is invaluable. We generally find farmers getting rich in proportion as they manure and improve their lands. The richest parts of Lancaster county, notwithstanding the superior quality of the soil, is generally manured better than any other in the State. No one can make farming pay without well manuring the land. A carpenter might as well try to work forever without sharpening his tools. Fifty dollars, judiciously expended in manure, will bring from three to five hundred dollars in return, and sometimes more. This soil should be manured at least as well as that of Pennsylvania. 


\section{Timber.}

Farms should have a good supply of timber. If it embraced one-third or one-fourth of the land it might not be too much. It can be had very cheap, and is a great convenience for the purposes of fuel or repairing, and, is a saving of expense. The growth will pay the interest on its first cost.

For brevity, these romarks may be sufficient; but your attention may as well be called to a matter of the highest importance, yet one so little thought of as to make its neglect in the present age a curious subject for reflection. The situation of this land for agricultural purposes, has more advantages than any general locality that can be found. This is striking. The mind may at once start back upon itself in questionable astonishment. The assertion may jar so much with all previous conception of the subject, as to elicit a smile of incredulity; but let us withdraw the reil of prejudice, and look into the light of reason and demonstration. The nearest line of the property is twenty-eight miles from Philadelphia, the farthest thirty-iive. It lies upon a Railroad leading directly to the last ramed city and New York; either place can be reached in onehalf the time between breakfast and dinner. The two greatest consuming markets in the Union are directly at hand, where the demand is greater than the supply. At the terminus of the road, within an hours ride, is Atlantic city, a place where, in summer time, on the average, there will be a population of some three thousand visitors. Here there will be a constant demand for light produce. Within the present year it is expected that a branch road will be built from Colville to Cape May, which will enlarge the advantages. But, independent of this, 
take only those that are in existence and actually secured, and whero is there a general locality in the United States that can exceed it. In the Spring, strawberries and all the luscious vegetables which are sought for with such avidity, can be gathered in the morning, and find a sale in either of the above mentioned cities before dinner time. Peaches, green corn, and the later products will find as ready a market. This cannot be denied, because it is truth, self evident, and when it is once admitted, any one, by employing a good agriculturalist, and taking a trip down upon the land, with a spade and auger in hand, can satisfy himself, that the soil is not surpassed in its richness by its superior locality. If a man has the industry and thrift to make a living anywhere upon a farm, he can make it here, and secure the independence which, above everything else, gires the occupation its charm.

\section{Remarks upon the Toun of Colville.}

Though farming is the intention of the Stockholders, yet as some have other occupations in view, a few remarks upon this subject may not be improper. There is no place offering more inducements to those who wish to carry on a business which can be followed away from the city than this. As a residence, it is particularly healthy and agreeable-the water is of the purest kind, and such a thing as fever and ague is unknown. It is destined to prosper, owing to the excellent opening it presents to business. There are many occupations pursued in the city, where people labor under the most exorbitant rents, which could as well be carried on here where living would cost comparatively little. Weavers of fancy stuffs, and mechanics of various kinds, who send in their work once a week, could as 
well and much better carry on their trades at Colvilute. There is also room for considerable traffic-it is one of the main stations for the cars, and a junction of numerous stage roads is formed-they lead to Weymouth Town, Emmelville, Walker's Forge, Estelville, 'Tuckahoe, Dennisville, Dyer's Creek, Goshen, Leedsville, Smith's Town, Cape May Court IIouse, Cold Spring, Cape May Island, Pleasant Mills, Badsto, Crowley Town, Green Bank, Lower Bank, Bass River, Tuckerton, McCarty'sville, and a number of others, from which passengers are constantly travelling to and fro. Owing to these advantages, it will soon be amply supplied with Stores, Shoemakers, Tailors, Blacksmiths, Wheelwrights, and all that is essential to a town. Improvements are taking an active start, and a neat and commodious Presbyterian Church will soon be in course of construction. For public accommodation, a large Hotel has been erected, with every convenience. A very fine bowling saloon is within about fifty feet of the main building, which will add both to the comfort and pleasure of visitors. A good Iivery Stable will also be connected with the Hotel.

Those who wish to build country cottages for summer residences, could not do better than by locating here. They would be but a short distance either from Philadelphia or the Sea Shore. They could go down to the beach and spend as much time as they might desire, and return the same afternoon-thus enjoying all the pleasures whilst they would avoid the dissipation and expense of a watering place. No resort could be found more susceptible of being made a pleasant one than this. The price of living is small, whilst such a fine opportunity is presented of laying out beautiful grounds and rural retreats, that I think all who want to luxuriate in flowers, shrubbery, and fruit, should make this place 
their peculiar choice. A cottage upon the fancy villa style, with ample grounds, capable of being beautifully adomed, forming a fine country lodge, could all be obtained at a trifling expense. There is access to and from the city twice each day.

Respectfully Your Friend,

And Fellow Associate,

Colville, May 1st, 1855.

CHAS. K. LANDIS, 


$$
\text { . }
$$




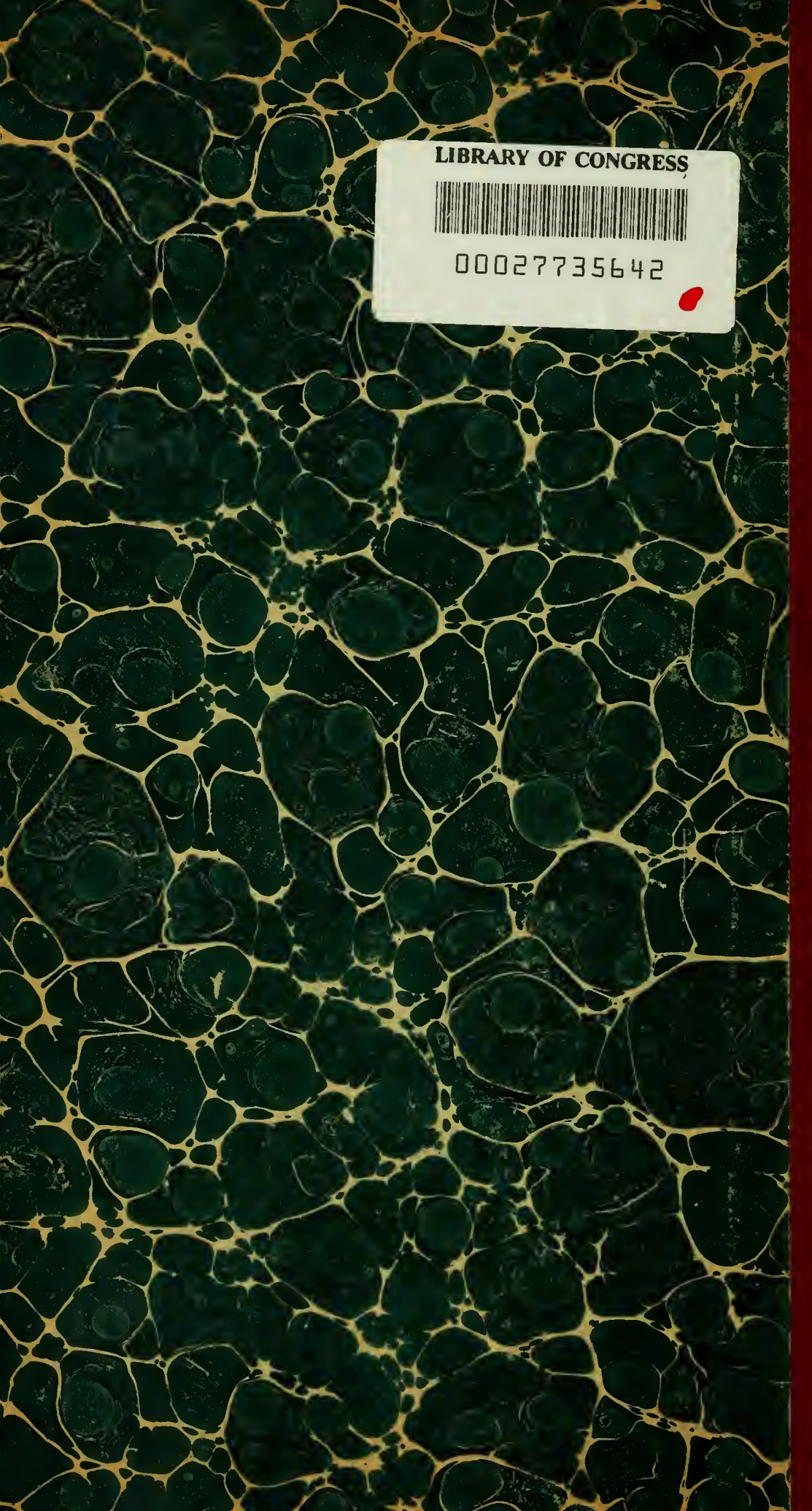

